\title{
HUBUNGAN KADAR KOLESTEROL DENGAN DERAJAT HIPERTENSI PADA PASIEN HIPERTENSI DI PUSKESMAS SUNGAI JINGAH
}

\author{
Solikin ${ }^{1}$, Muradi $^{2}$ \\ 1,2Staff Dosen Fakultas Keperawatan Dan Ilmu Kesehatan \\ Universitas Muhammadiyah Banjarmasin, 70114, Indonesia
}

Email: solikin@umbjm.ac.id

\begin{abstract}
Abstrak
Latar belakang : Kolesterol merupakan masalah kompleks dalam tubuh manusia. Penyempitan serta kakunya dinding pembuluh darah akibat dari penumpukan kolesterol pada pembuluh dapat menyebabkan tekanan darah meningkat. Tujuan penelitian ini untuk mengetahui Hubungan Kadar Kolesterol Dengan Derajat Hipertensi Pada Pasien Hipertensi Di Puskesmas Sungai Jingah Tahun 2019.

Metode : Jenis penelitian menggunakan pendekatan/rancangan dengan model pendekatan/rancangan cross-sectional. Sampel dalam penelitian ini sebanyak 41 responden. Tekanan darah diukur dengan sphygmomanometer pegas, sedangkan kadar kolesterol diukur dari hasil pemeriksaan laboratorium dengan pengambilan sampel menggunakan metode kolorimetrik enzimatik CHOD-PAP. Uji statistik yang digunakan adalah uji spearman rank. Hasil : Hasil yang diperoleh pada analisis spearman's rho menunjukkan bahwa dari 41 responden diperoleh nilai signifikan sebesar 0,004 yang lebih kecil dari 0,1 sebagai taraf yang telah ditentukan sehingga dapat dinyatakan hipotesis diterima yang secara uji statistik terdapat hubungan yang bermakna antara kadar kolesterol darah dengan derajat hipertensi.

Kesimpulan : Dalam mengendalikan kadar kolesterol maka penting bagi pasien untuk menjaga kesehatan dengan cara menjaga gaya hidup sehat dan selalu mengontrol kadar kolesterol dan tekanan darah sehingga terhindar dari komplikasi penyakit akibat tinggi kolesterol dan hipertensi.
\end{abstract}

Kata Kunci : Derajat Hipertensi, Kadar Kolesterol. 


\section{LATAR BELAKANG}

Kolesterol merupakan masalah kompleks dalam tubuh manusia. Menjadi sebuah dilema bagi siapapun yang belum tahu betul manfaat dan bahaya kolesterol. Disatu sisi memiliki manfaat yang baik dalam tubuh manusia disisi lain kolesterol sangat berbahaya dalam tubuh apabila jumlah kolesterol jahat (low density lipoprotein) mendominasi jumlah kolesterol baik (high density lipoprotein) bisa menyebabkan beberapa penyakit seperti, penyakit jantung, diabetes, dan aterosklerosis. Kolesterol adalah salah satu komponen dalam membentuk lemak. Di dalam lemak terdapat berbagai macam komponen yaitu seperti zat trigliserida, fosfolipid, asam lemak bebas, dan juga kolesterol. Secara umum, kolesterol berfungsi untuk membangun dinding didalam sel (membran sel) dalam tubuh (Mumpuni \& Wulandari, 2011). Hipertensi atau penyakit tekanan darah tinggi merupakan suatu keadaan kronis yang ditandai dengan meningkatnya tekanan darah pada dinding pembuluh darah arteri. Keadaan tersebut mengakibatkan jantung bekerja lebih keras untuk mengedarkan darah ke seluruh tubuh melalui pembuluh darah, hal ini dapat mengganggu aliran darah, merusak pembuluh darah, bahkan menyebabkan penyakit degeneratif, hingga kematian (Sari, 2017).

Tahun 2016 di Amerika Serikat lebih dari 12 persen orang dewasa mengalami peningkatan kolesterol (National Center for Health Statistics, 2017), dan tahun 2017 angka kejadian hiperkolesterolemia sebanyak 40\% (American Heart Association, 2017), sedangkan pada tahun 2018 meningkat menjadi 48,6\% (American Heart Association, 2018). Di Indonesia, angka kejadian hiperkolesterolemia menurut penelitian MONICA I (Multinational Monitoring of Trends Daterminants in Cardiovascular Disease) sebesar 13,4\% pada wanita dan 11,4\% pria. Pada MONICA 2 II didapatkan meningkat menjadi $16,2 \%$ pada wanita dan 14\% pria (Ayuandira, 2012). Diperkirakan sekitar $35 \%$ penduduk Indonesia memiliki kadar kolesterol lebih tinggi dari batas normal.

Berdasarkan data Riskesdas (Riset Kesehatan Dasar) tahun 2013 proporsi penduduk Indonesia dengan kadar kolesterol total di atas normal lebih tinggi pada perempuan $(39,6 \%)$ dibandingkan pada lakilaki $(30,0 \%)$ dan di daerah perkotaan lebih tinggi daripada daerah pedesaan (Departemen Kesehatan, 2013). Pada tahun 2017 angka kejadian hiperkolesterolemia sebanyak 39,8 \% (Perhimpunan Dokter Spesialis Kardiovaskular Indonesia, 2017).

Tahun 2016 di Amerika Serikat angka kejadian hipertensi sebanyak 29,0\% (NCHS, 2017), pada tahun 2017 angka kejadian hipertensi meningkat menjadi 45,0 persen (AHA, 2017), dan pada tahun 2018 diperkirakan 103 juta orang dewasa Amerika Serikat memiliki tekanan darah tinggi, menurut statistik baru dari AHA tahun 2018. Survei Indikator kesehatan Nasional (Sirkesnas) pada tahun 2016 menyebutkan adanya persentase penduduk yang mengidap hipertensi sebanyak 30,9\%, pada tahun 2017 berdasarkan Profil Kesehatan RI prevalensi hipertensi sebanyak 30,9\%, berdasrakan Riskesdes tahun 2018 yang diterbitkan kementrian kesehatan diketahui prevalensi hipertensi sebanyak $34,1 \%$. Setiap tahunnya di Indonesia jumlah penderita hipertensi mengalami peningkatan.

Sejalan dengan hal tersebut, Data Dinas Kesehatan Provinsi Kalimantan Selatan menunjukan bahwa di wilayah provinsi Kalimantan Selatan angka kejadian 
hipertensi pada tahun 2016 sebanyak 57.875 orang, pada tahun 2017 sebanyak 181.507 orang, dan pada tahun 2018 sebanyak 203.483 orang. Setiap tahunnya di daerah provinsi Kalimantan Selatan jumlah penderita hipertensi mengalami peningkatan. Berdasarkan data dari Dinas Kesehatan Kabupaten Kota Banjarmasin tahun 2018 angka kejadian hiperkolesterolemia sebanyak 9.889 orang, kejadian hiperkolesterolemia tertinggi di daerah kerja puskesmas Cempaka dengan angka kejadian 1.472 orang, dan yang terendah di daerah kerja puskesmas Sungai Mesa dengan angka kejadian 17 orang, pada puskesmas Sungai Jingah kejadian hiperkolesterolemia sebanyak 177 orang (Dinas Kesehatan Kota 2019).

Berbanding lurus dengan data laporan tahunan Dinas Kesehatan Kota Banjarmasin Tahun 2016 sebanyak 80.850 orang dengan hipertensi dan kejadian tertinggi berada pada wilayah puskesmas Cempaka sebanyak 5.509 orang dan terendah pada puskesmas Alalak Tengah sebanyak 672 orang dan pada wilayah puskesmas Sungai Jingah sebanyak 4.018 orang. Pada tahun 2017 angka kejadian hipertensi sebanyak 76.548 orang dan kejadian tertinggi berada pada wilayah puskesmas Cempaka sebanyak 5.832 orang dan terendah pada puskesmas Kayutangi sebanyak 314 orang dan pada wilayah puskesmas Sungai Jingah sebanyak 4.485 orang. Pada tahun 2018 hipertensi merupakan penyakit dengan kasus nomor satu terbanyak sebanyak 78.097 orang dan kejadian tertinggi berada pada wilayah puskesmas Gedang Hanyar sebanyak 5.426 orang dan terendah pada puskesmas Alalak Tengah sebanyak 639 orang dan pada wilayah puskesmas Sungai Jingah sebanyak 5.140 orang (Dinkes, 2019). Angka kejadian hipertensi di wilayah Banjarmasin juga semakin bertambah setiap tahunnya.
Menurut laporan tahunan Puskesmas Sungai Jingah dari tahun 2016 jumlah kasus hipertensi tercatat 4.018 penderita dan pada tahun 2017 jumlah kasus hipertensi tercatat 4.485 penderita. Pada tahun 2018 jumlah kasus hipertensi tercatat 5.140 penderita. Angka kejadian hipertensi di Puskesmas Sungai Jingah juga semakin bertambah setiap tahunnya (Dinkes Kota 2019).

Hipertensi meningkatkan risiko penyakit jantung dua kali dan meningkatkan risiko stroke delapan kali dibanding dengan orang yang tidak mengalami hipertensi. Selain itu hipertensi juga menyebabkan payah jantung, gangguan pada ginjal dan retinopati. Hal ini akan sangat membahayakan jika tidak dikontrol dengan baik (Tian et al, 2011). Penyebab kenaikan tekanan darah sulit dipastikan secara pasti karena faktor yang memicu kenaikan tekanan darah sangat banyak dan bersifat spesifik untuk setiap individu. Kurangnya aktivitas fisik dapat meningkatkan kadar kolesterol dalam tubuh yang menjadi faktor risiko penyakit jantung dan pembuluh darah (Ruslianti, 2014). Kolesterol merupakan faktor resiko yang dapat dirubah dari hipertensi, kolesterol itu sendiri ialah suatu substansi seperti lilin yang berwarna putih, secara alami ditemukan di dalam tubuh. Kolesterol diproduksi di hati, fungsinya untuk membangun dinding sel dan membuat hormon-hormon tertentu, seperti hormon adrenal korteks, estrogen, andogen, dan progesteron (Fujikawa, Iguchi, Noguchi, \& Sasaki, 2015).

Penelitian jantung oleh Framingham di Amerika menyatakan bahwa adanya hubungan antara kadar kolesterol dengan tekanan darah. Para dokter di Amerika meneliti data dari ribuan wanita dan menemukan bahwa semakin tinggi kadar kolesterol pada wanita paruh baya, semakin 
rentan dirinya mengalami hipertensi. Sebaliknya, pada wanita dengan jumlah high density lipoprotein tinggi, resiko hipertensi sedikit lebih rendah (Nikolov et al., 2015). Pada beberapa penelitian di Norwegia, Belanda, Selandia baru dan Inggris, pada kurang lebih 5000 pasien hipertensi di dapatkan sekitar $91 \%$ diantaranya mengalami hiperkolesterolemia (Harefa, 2009).

Kadar kolesterol darah yang tinggi banyak dialami oleh penderita hipertensi. Kadar kolesterol yang tinggi dapat membentuk plak yang timbul pada permukaan dinding arteri. Hal ini menyebabkan diameter pembuluh darah mengecil (aterosklerosis). Adanya sumbatan dalam pembuluh darah akan menyebabkan lumen (lubang) pembuluh darah menjadi sempit dan elastis dinding pembuluh berkurang, sehingga menyebabkan tekanan darah meninggi. Tekanan darah meningkat dikarenakan timbunan kolesterol pada dinding pembuluh darah yang berlebihan. Kolesterol dalam tubuh yang berlebihan akan tertimbun di dalam dinding pembuluh darah dan menimbulkan suatu kondisi yang disebut aterosklerosis yaitu penyempitan atau pengerasan pembuluh darah. Kondisi ini merupakan cikal bakal terjadinya penyakit jantung dan stroke. WHO memperkirakan, $20 \%$ kejadian stroke dan lebih dari $50 \%$ serangan jantung disebabkan karena kadar kolesterol yang tinggi (Susilo, et al, 2011).

Penelitian ini dilakukan di Puskesmas Sungai Jingah dikarenakan setiap tahunnya angka kejadian hipertensi dalam 3 tahun terakhir semakin meningkat, serta terbanyak nomor 2 setelah Puskesmas Gedang Hanyar pada tahun 2018 (Dinkes Kota Banjarmasin). Studi pendahuluan yang dilakukan di Puskesmas Sungai Jingah dengan cara wawancara didapatkan bahwa 10 responden memang benar pasien hipertensi dan peneliti mengobservasi terhadap 10 orang pasien hipertensi menggunakan shpymomanometer dan alat pemeriksa kolesterol didapatkan bahwa 4 orang (40\%) derajat I, 5 orang (50\%) mengidap hipertensi derajat II, dan 1 orang (10\%) derajat III. Sedangkan 7 orang (70\%) dari 10 pasien hipertensi mengalami peningkatan kolesterol (hiperkolesterolemia $>200 \mathrm{mg} / \mathrm{dl}$ ). Pasien hipertensi yang mengalami hiperkolesterolemia terbagi dari beberapa derajat hipertensi yaitu; 2 orang (20\%) derajat I, 4 orang (40\%) derajat II, dan 1 orang $(10 \%)$ derajat III.

Berdasarkan latar belakang di atas dan data angka kejadian hipertensi yang semakin meningkat setiap tahunnya. maka dari itu penulis tertarik untuk melakukan penelitian tentang "Hubungan Kadar Kolesterol Dengan Derajat Hipertensi Pada Pasien Hipertensi Di Puskesmas Sungai Jingah Tahun 2019".

\section{METODE PENELITIAN}

Penelitian ini menggunakan pendekatan/rancangan dengan model pendekatan/rancangan cross-sectional. Populasi dalam penelitian ini jumlah ratarata penderita hipertensi yang berkunjung dalam tiga bulan terakhir sebanyak 67 penderita hipertensi yang datang ke Puskesmas Sungai Jingah tahun 2019. Jumlah sampel dalam penelitian ini sebanyak 41 responden. Teknik pengambilan sampel pada penelitian ini yaitu dengan menggunakan teknik Nonprobability

Sampling atau dengan pendekatan Purposif Sampling

Dengan kriteria inklusi: responden berusia mulai 35 sampai dengan 68 tahun, responden tidak memilik penyakit hipertensi sekunder (penyakit ginjal, penyakit pembuluh darah, penyakit endokrin, dll), responden tidak mengkonsumsi obat anti hipertensi selama 24 jam terakhir, responden 
sudah dalam kondisi tenang sebelum pemeriksaan sudah menunggu \pm 15 menit di ruang tunggu. Kriteria eklusi: responden dengan anemia, responden yang mengkonsumsi obat-obat yang mempengaruhi tekanan darah, responden yang mengkonsumsi obat penurun kadar kolesterol sebelum diperiksa.

Analisis menggunakan uji Sperman Rank, analisis ini dilakukan dengan bantuan perangkat komputer dengan menggunakan tingkat kepercayaan 90\%. Uji statistik koefisien korelasi spearman rank tersebut dengan taraf kesalahan $10 \%$. Hasil yang diperoleh pada analisis Spearman's rho menunjukkan bahwa dari 41 responden diperoleh nilai signifikan sebesar 0,004 yang lebih kecil dari 0,1 sebagai taraf yang telah ditentukan sehingga dapat dinyatakan Hipotesis diterima yang secara uji statistik terdapat hubungan yang bermakna antara kadar kolesterol darah dengan derajat hipertensi.

\section{HASIL}

Tabel 1. Karakteristik Responden Berdasarkan Jenis Kelamin

\begin{tabular}{|l|l|l|l|}
\hline No. & Jenis Kelamin & Jumlah & $\%$ \\
\hline 1. & Laki-laki & 17 & 41,46 \\
\hline 2. & Perempuan & 24 & 58,54 \\
\hline \multicolumn{2}{|l|}{ Total } & 41 & 100,00 \\
\hline
\end{tabular}

Tabel 1 menunjukkan karakteristik responden berdasarkan jenis kelamin paling banyak adalah responden perempuan berjumlah 24 responden $(58,54 \%)$.

Tabel 2. Karakteristik Responden Berdasarkan Umur

\begin{tabular}{|l|l|l|l|}
\hline No. & Umur & Jumlah & $\%$ \\
\hline 1. & $35-44$ & 8 & 19,51 \\
\hline
\end{tabular}

\begin{tabular}{|l|l|l|l|}
\hline 2. & $45-54$ & 18 & 43,90 \\
\hline 3. & $55-64$ & 14 & 34,15 \\
\hline 4. & $65-68$ & 1 & 2,44 \\
\hline \multicolumn{2}{|l|}{ Total } & 41 & 100,00 \\
\hline
\end{tabular}

Tabel 2 menunjukkan karakteristik responden berdasarkan umur paling banyak adalah responden dengan rentang umur 4554 tahun berjumlah 18 responden $(43,90 \%)$, dan paling sedikit adalah responden dengan rentang umur 65-68 tahun berjumlah 1 responden $(2,44 \%)$.

\section{Analisa univariat}

Tabel 2. Distribusi jumlah kadar kolesterol darah di puskesmas sungai jingah

\begin{tabular}{|l|l|l|l|}
\hline No. & Kadar Kolesterol & Jumlah & $\%$ \\
\hline 1. & Normal & 8 & 19,51 \\
\hline 2. & Batas Tinggi & 27 & 65,85 \\
\hline 3. & Hiperkolesterolemia/Tinggi & 6 & 14,63 \\
\hline Total & 41 & 100,00 \\
\hline
\end{tabular}

Didapatkan hasil kadar kolesterol paling banyak adalah kadar kolesterol batas tinggi berjumlah 27 responden $(65,85 \%)$ dan paling sedikit adalah kadar kolesterol tinggi berjumlah 6 orang $(14,63 \%)$.

Tabel 3. Distribusi jumlah derajat hipertensi di puskesmas sungai jingah

\begin{tabular}{|l|l|l|l|}
\hline No. & Derajat Hipertensi & Jumlah & $\%$ \\
\hline 1. & Derajat 1 & 10 & 24,39 \\
\hline 2. & Derajat 2 & 27 & 65,85 \\
\hline 3. & Derajat 3 & 4 & 9,76 \\
\hline \multicolumn{2}{|l|}{ Total } & 41 & 100,00 \\
\hline
\end{tabular}

Didapatkan hasil derajat hipertensi paling banyak adalah derajat 2 berjumlah 27 responden $(65,85 \%)$, dan derajat hipertensi paling sedikit adalah derajat 2I sebanyak 4 responden $(9,76 \%)$. 


\section{Analisa Bivariat}

Tabel 4. Hubungan kadar kolesterol dengan derajat hipertensi

\begin{tabular}{|c|c|c|c|c|c|c|c|c|c|c|}
\hline & \multicolumn{6}{|c|}{ Derajat Hipertensi } & \multirow[t]{2}{*}{ Tota } & \multirow{2}{*}{$\%$} & \multirow{2}{*}{$\begin{array}{c}\mathrm{P} \\
\text { Value }\end{array}$} \\
\hline & & 1 & $\%$ & 2 & $\%$ & 3 & $\%$ & & & \\
\hline \multirow{3}{*}{$\begin{array}{c}\text { Kadar } \\
\text { Koles } \\
\text { terol }\end{array}$} & $\begin{array}{c}\text { Norm } \\
\text { al }\end{array}$ & 6 & $\begin{array}{l}77 \\
5\end{array}$ & 1 & $\begin{array}{l}2 \\
5\end{array}$ & 1 & 25 & 8 & 100 & \multirow{4}{*}{0,004} \\
\hline & $\begin{array}{l}\text { Batas } \\
\text { Tingg }\end{array}$ & 3 & 11,1 & 23 & 85,1 & 1 & 3,7 & $\begin{array}{l}2 \\
7\end{array}$ & 100 & \\
\hline & $\begin{array}{l}\text { Hiper } \\
\text { kolest } \\
\text { erole } \\
\text { mia }\end{array}$ & 1 & 16,6 & 3 & 50 & 2 & 33,3 & 6 & 100 & \\
\hline \multicolumn{2}{|c|}{ Total } & 10 & 24,3 & 27 & 65,8 & 4 & 9,7 & $\begin{array}{l}4 \\
1\end{array}$ & 100 & \\
\hline
\end{tabular}

Hasil analisis menunjukkan bahwa dari 41 responden dengan kadar kolesterol normal paling banyak adalah hipertensi derajat I berjumlah 6 responden $(75,0 \%)$. Dan responden dengan kadar kolesterol batas tinggi paling banyak adalah hipertensi derajat 2 yaitu sebanyak 23 responden $(85,2 \%)$. Kemudian responden dengan kadar kolesterol tinggi paling banyak adalah hipertensi derajat 2 sebanyak 3 orang $(50,0 \%)$. Hasil yang diperoleh pada analisis Spearman's rho menunjukkan bahwa dari 41 responden diperoleh nilai signifikan sebesar 0,004 yang lebih kecil dari 0,1 sebagai taraf yang telah ditentukan sehingga dapat dinyatakan Hipotesis diterima yang secara uji statistik terdapat hubungan yang bermakna antara kadar kolesterol darah dengan derajat hipertensi.

\section{PEMBAHASAN}

\section{Mengidentifikasi kadar kolesterol pada pasien hipertensi.}

Berdasarkan hasil penelitian dari 41 responden hipertensi didapatkan hasil kadar kolesterol paling banyak adalah kadar kolesterol dengan batas tinggi berjumlah 27 responden $(65,85 \%)$. Hal ini menunjukkan bahwa dalam penelitian ini pasien hipertensi cendrung lebih banyak mengalami peningkatan kadar kolesterol.

Menurut Susilo, et al, (2011) kadar kolesterol darah yang tinggi banyak dialami oleh penderita hipertensi. Kadar kolesterol yang tinggi dapat membentuk plak yang timbul pada permukaan dinding arteri. Hal ini menyebabkan diameter pembuluh darah mengecil (aterosklerosis). Adanya sumbatan dalam pembuluh darah akan menyebabkan lumen (lubang) pembuluh darah menjadi sempit dan elastis dinding pembuluh berkurang, sehingga menyebabkan tekanan darah meninggi. Tekanan darah meningkat dikarenakan timbunan kolesterol pada dinding pembuluh darah yang berlebihan. Kolesterol dalam tubuh yang berlebihan akan tertimbun di dalam dinding pembuluh darah dan menimbulkan suatu kondisi yang disebut aterosklerosis yaitu penyempitan atau pengerasan pembuluh darah. Kondisi ini merupakan cikal bakal terjadinya penyakit jantung dan stroke. Teori lain juga mengatakan bahwa kadar kolesterol darah yang tinggi dapat mengakibatkan terjadinya endapan kolesterol dalam dinding pembuluh darah. Lama-kelamaan, jika endapan kolesterol bertambah akan menyumbat pembuluh nadi dan menganggu peredaran darah, sehingga memperberat kerja jantung dan secara tidak langsung memperparah hipertensi (Lany, 2008).

Berdasarkan hasil dari penelitian ini juga didapatkan bahwa dari 27 responden yang mempunyai kadar kolesterol batas tinggi dengan karakteristik jenis kelamin paling banyak adalah jenis kelamin perempuan berjumlah 18 responden $(66,7 \%)$. Hal ini menunjukkan bahwa perempuan cenderung lebih banyak mengalami peningkatan kadar kolesterol dibandingkan 
laki-laki. Sejalan dengan penelitian yang dilakukan oleh Sudaryanto (2019) diketahui bahwa peningkatan kadar kolesterol total lebih beresiko dialami perempuan daripada laki-laki. Berdasarkan hasil penelitian Sri Ujiani (2016) menunjukkan bahwa ada hubungan yang bermakna antara jenis kelamin dengan kadar kolesterol. Jenis kelamin perempuan lebih cenderung mengalami peningkatan kadar kolesterol dibandingkan laki-laki.

Penelitian ini jika dikaitkan antara usia dengan kadar kolesterol didapatkan bahwa dari 27 responden yang mempunyai kadar kolesterol batas tinggi dengan karakteristik umur paling banyak adalah rentang umur 4554 berjumlah 13 responden $(48,1 \%)$. Hal ini menunjukkan bahwa peningkatan kolesterol cendrung lebih banyak terjadi pada usia 45 tahun lebih. Berdasarkan hasil penelitian Lilis Sugiarti (2018) menunjukkan bahwa semakin usia seseorang menua kemungkinan besar kadar kolesterol meningkat. Menurut (Shabela, 2012) mengatakana usia yang semakin meningkat juga salah satu penyebab kolesterol tinggi yang diakibatkan menurunnya daya kinerja organ tubuh.

\section{Mengidentifikasi derajat hipertensi pada pasien hipertensi.}

Berdasarkan hasil penelitian dari 41 responden didapatkan hasil derajat hipertensi paling banyak adalah derajat hipertensi dengan derajat 2 berjumlah 27 responden $(65,85 \%)$.

Berdasarkan hasil dari penelitian ini didapatkan bahwa dari 27 responden yang mempunyai hipertensi derajat 2 dengan karakteristik jenis kelamin paling banyak adalah jenis kelamin perempuan berjumlah 20 responden $(74,1 \%)$. Hal ini menunjukkan bahwa perempuan cenderung lebih banyak mengalami peningkatan tekanan darah dibandingkan laki-laki. Menurut Oktora (2007), wanita lebih banyak menderita hipertensi dibandingkan dengan pria yaitu $58 \%$ banding $42 \%$. Hal ini juga menyebabkan resiko wanita untuk terkena penyakit jantung menjadi lebih tinggi. Teori lain juga mengatakan bahwa hubungan jenis kelamin dengan kejadian hipertensi pada pasien yang berobat di Poliklinik Dewasa Puskesmas Bangkinang didapatkan hasil bahwa wanita lebih banyak menderita hipertensi dibandingkan dengan pria yaitu $51 \%$ banding $49 \%$ (Rayhani, 2013). Menurut Miller (2010) perubahan hormonal yang sering terjadi pada wanita menyebabkan wanita lebih cenderung memiliki tekanan darah tinggi. Didukung dengan hasil penelitian Jajuk Kusumawaty (2016) bahwa jenis kelamin yang terbanyak mengalami kejadian hipertensi adalah perempuan.

Berdasarkan hasil penelitian ini dari 27 responden yang mempunyai hipertensi derajat 2 dengan umur paling banyak adalah rentang umur 45-54 berjumlah 15 responden $(55,5 \%)$. Hal ini menunjukkan makin tinggi usia seseorang maka resiko mengalami tekanan darah tinggi juga meningkat. Menurut Rahajeng dan Tuminah (2009) tingginya hipertensi sejalan dengan bertambahnya umur yang disebabkan oleh perubahan struktur pada pembuluh darah besar, sehingga pembuluh darah menjadi lebih sempit dan dinding pembuluh darah menjadi kaku, sebagai akibatnya adalah meningkatnya tekanan darah sistolik. Didukung dengan penelitian Fajar Apriyandi (2010) yang menunjukkan hasil terdapat hubungan yang bermakna antara peningkatan usia dengan kejadian hipertensi. Teori lain juga mengatakan bahwa usia salah satu faktor risiko terjadinya hipertensi yang tidak dapat diubah. Pada umumnya semakin bertambahnya usia maka semakin besar pula 
risiko terjadinya hipertensi. Hal tersebut disebabkan oleh perubahan struktur pembuluh darah seperti; penyempitan lumen, serta dinding pembuluh darah menjadi kaku dan elastisitasnya berkurang sehingga meningkatkan tekanan darah (Sari, 2017).

Hubungan kadar kolesterol darah dengan derajat hipertensi pada pasien hipertensi.

Berdasarkan hasil penelitian menunjukkan bahwa hasil analisis Spearman's rho dari 41 responden diperoleh nilai signifikan yakni sebesar 0,004 yang lebih kecil dari 0,1 sebagai taraf yang telah ditentukan ( $\mathrm{r}$ hitung $\leq \alpha)$ dan dapat dinyatakan Hipotesis diterima yang secara uji statistik terdapat hubungan yang bermakna antara kadar kolesterol dengan derajat hipertensi.

Berdasarkan hasil penelitian pada tabel 4.6 menunjukkan bahwa dari 41 responden didapatkan hasil derajat hipertensi paling banyak adalah derajat hipertensi dengan derajat 2 berjumlah 27 responden $(65,85 \%)$ dan mengalami kadar kolesterol batas tinggi berjumlah 23 responden $(85,1 \%)$. Hal ini menunjukkan bahwa peningkatan tekanan darah sejalan dengan peningkatan kadar kolesterol. Menurut Lany (2008) kadar kolesterol darah yang tinggi dapat mengakibatkan terjadinya endapan kolesterol dalam dinding pembuluh darah. Lamakelamaan, jika endapan kolesterol bertambah akan menyumbat pembuluh nadi dan menganggu peredaran darah, sehingga memperberat kerja jantung dan secara tidak langsung memperparah hipertensi. Jadi, kadar kolesterol yang tinggi dapat memperparah hipertensi.

Tahun 2006 Physicians' health study membandingkan kadar kolesterol pada pria hipertensi dengan kadar kolesterol pada pria bertekanan darah normal. Resiko perkembangan hipertensi pada pria dengan kadar kolesterol tinggi lebih besar (23\%) daripada pria dengan kadar kolesterol yang normal (Harefa, 2009). Penelitian yang dilakukan oleh Framingham menyatakan bahwa adanya hubungan antara kadar kolesterol dengan tekanan darah. Pada tahun 2006 para dokter di Amerika meneliti data dari ribuan wanita dan menemukan bahwa semakin tinggi kadar kolesterol pada wanita paruh baya, semakin rentan dirinya mengalami hipertensi. Sebaliknya, pada wanita dengan jumlah high density lipoprotein tinggi, resiko hipertensi sedikit lebih rendah (Nikolov et al., 2015). Jadi, kolesterol menjadi salah satu faktor yang dapat menimbulkan hipertensi. Kolesterol salah satu faktor resiko yang dapat dirubah dari hipertensi, semakin tinggi kadar kolesterol total maka akan semakin tinggi kemungkinan terjadinya hipertensi (Fujikawa, Iguchi, Noguchi, \& Sasaki, 2015).

Teori lain juga mengatakan kadar kolesterol darah yang tinggi dapat mengakibatkan terjadinya endapan kolesterol dalam dinding pembuluh darah. Lamakelamaan, jika endapan kolesterol bertambah akan menyumbat pembuluh nadi dan menganggu peredaran darah, sehingga memperberat kerja jantung dan secara tidak langsung memperparah hipertensi (Lany, 2008). Jadi, kadar kolesterol menjadi salah satu faktor yang dapat menimbulkan hipertensi, dan memperparah hipertensi.

Penelitian yang dilakukan oleh Heni Maryati pada tahun 2017 juga mengatakan bahwa ada Hubungan Kadar Kolesterol Dengan Tekanan Darah Penderita Hipertensi Di Dusun Sidomulyo Desa Rejoagung Kecamatan Ploso Kabupaten Jombang dengan menggunakan metode cross sectional (Hasanah, Uswatun., Maryati, 
Heni., Nahariani, pepin. 2017). Ada beberapa penelitian yang dilakukan pada orang dewasa Indonesia membuktikan bahwa adanya hubungan antara kadar kolesterol total dengan tekanan darah sistolik dan diastolik (Margarita, et al., 2013). Jadi, dari hasil penelitian tersebut menyatakan bahwa ada hubungan kadar kolesterol dengan tekanan darah, yang sejalan dengan hasil penelitian ini bahwa terdapat hubungan antara kadar kolesterol dengan derajat hipertensi.

Berdasarkan hasil penelitian menunjukkan bahwa dari 41 responden didapatkan dari kadar kolesterol normal dengan derajat hipertensi 3 berjumlah 1 responden $(25 \%)$ dan dari kadar kolesterol tinggi dengan derajat hipertensi 1 berjumlah 1 responden (16,6\%). Penelitian ini menunjukkan bahwa walaupun memiliki kadar kolesterol normal pasien hipertensi masih ada memiliki derajat hipertensi yang tinggi yaitu derajat 3, dan walaupun memiliki kadar kolesterol tinggi pasien hipertensi masih ada memiliki hipertensi yang rendah yaitu derajat 1. Hal ini menunjukkan bahwa kadar kolesterol dan hipertensi dipengaruhi oleh beberapa factor lain. Menurut Shabela (2012) kadar kolesterol dipengaruhi oleh beberapa faktor seperti genetik, gaya hidup, usia, dan aktivitas fisik. Beberapa faktor yang dapat menyebabkan peningkatan tekanan darah diantaranya adalah usia, ras, jenis kelamin, stress, medikasi, variasi diural, olah raga dan hormonal (Sudoyo, et, al, 2014).

\section{KESIMPULAN}

Berdasarkan hasil penelitian yang telah dilakukan tentang Hubungan Kadar Kolesterol Darah Dengan Derajat Hipertensi Pada Pasien Hipertensi Di Puskesmas Sungai Jingah Tahun 2019 Terhadap 41 responden mengacu pada tujuan penelitian ini dapat ditarik kesimpulan sebagai berikut : Kadar kolesterol darah responden sebagian besar adalah kadar kolesterol darah dengan batas tinggi sebanyak 27 responden $(65,58 \%)$. Derajat hipertensi responden sebagian besar adalah berada pada hipertensi derajat II sebanyak 27 orang $(65,85 \%)$. Terdapat hubungan antara kadar kolesterol darah dengan derajat hipertensi pada pasien hipertensi di Puskesmas Sungai Jingah Tahun 2019 dengan nilai signifikan 0,004.

\section{SARAN}

Bagi Pasien Hipertensi: Responden lebihbisa lagi mengendalikan kadar kolesterol dan pentingnya menjaga kesehatan agar terhindar dari komplikasi penyakit akibat tinggi kolesterol dan hipertensi, dengan cara menjaga gaya hidup sehat dan selalu mengontrol kadar kolesterol dan tekanan darah.

Bagi Institusi Pendidikan: Hasil penelitian ini diharapkan dapat memperkaya bahan pustaka dan menambah wawasan serta pengetahuan bagi mahasiswa lain yang ingin melakukan penelitian lebih lanjut. Dan institusi pendidikan dapat memfasilitasi berbagai kegiatan kemahasiswaan melalui kegiatan program promosi kesehatan terutama program yang berhubungan dengan meningkatkan kemandirian pasien dalam mengelola hipertensi maupun pengendalian kolesterol.

Bagi Peneliti Selanjutnya: Peneliti selanjutnya dapat meneliti lebih lanjut terkait faktor lain yang mempengaruhi terhadap derajat hipertensi seperti obesitas, stress, dan umur.

Bagi Puskesmas: Puskesmas sebagai layanan kesehatan dapat mengembangkan program-program kesehatan untuk mengurangi peningkatan kadar kolesterol dan angka kejadian Hipertensi, seperti membuat program pendidikan kesehatan dengan penyuluhan rutin yang berfokus 
kepada pengendalian kolesterol dan tekanan darah yang dilakukan setiap minggu.

\section{DAFTAR PUSTAKA}

American Heart Association (AHA). (2014, 2017, 2018). Classes of Heart Failure.

Dinas Kesehatan Kota Banjarmasin. (2019).

Profil Dinas Kesehatan Kota Banjarmasin tahun 2018, 2017, 2016: Banjarmasin.

Dinas Kesehatan Provinsi Kalimantan Selatan. (2019). Profil Dinas Kesehatan Provinsi Kalimantan Selatan tahun 2018, 2017, 2016: Kalimantan Selatan.

Fujikawa, S., Iguchi, R., Noguchi, T., \& Sasaki, M. (2015). Cholesterol crystal embolization following urinary diversion: a case report. Hinyokika Kiyo. Acta Urologica Japonica, 61(3), 99-102.

Hasanah, Uswatun., Maryati, Heni., Nahariani, pepin. (2017). Hubungan Self Efficacy Dengan Kecemasan Penderita Gagal Ginjal Kronik Yang Menjalani Hemodialisa Di Rsud Jombang. Progam Studi S1 Keperawatan STIKES Pemkab Jombang. Jurnal Ilmiah Kesehatan, Vol. 10, No. 1, Februari 2017.

Kusumawaty, Jajuk., Nur hidayat, eko ginanjar. (2016). Hubungan jenis kelamin dengan intensias hipertensi pada lansia di wilayah kerja puskesmas lakbok kabupaten ciamin. Jurnal mutiara medika. Vol 16 no 2:46-51.

Laporan Hasil Riset Kesehatan Dasar (Riskesdas). (2018). Departemen Kesehatan Republik Indonesia. Jakarta. Margarita, Yohana., Princen, Andi, Marcella Erwina Rumawas, Valentinus Budi Kidarsa, Bambang Sutrisna. (2013).
Kadar Kolesterol Total Dan Tekanan Darah Orang Dewasa Indonesia. Kesmas National Public Health Journal p-ISSN: 1907-7505, Vol 8 No 2.

Nikolov, P., Nikolova, J., Orbecova, M., Deneva, T., Vladimirova, L., Atanasova, P. Nikolov, F. (2015). Flow Mediated Vasodilation and Some Biomarkers of Endothelial Activation in Pre-Hypertensive Objects. The West Indian Medical Journal. Doi : 10.7727/wimj.2015.033.

Perhimpunan Dokter Spesialis Kardiovaskular Indonesia (PERKI). (2017). Pedoman Tatalaksana Dislipidemia.

Profil Kesehatan Republik Indonesia. (2017). Departemen Kesehatan Republik Indonesia: Jakarta.

Puskesmas Sungai Jingah. (2019) Profil Puskesmas Sungai Jingah tahun 2018, 2017, 2016: Banjarmasin.

Sari, Yanita Nur Indah. (2017). Berdamai dengan Hipertensi. Jakarta: Bumi Medika.

Sudoyo AW, Setiyohadi B, Alwi I, Simadibrata M, Setiati S. (2014). Buku Ajar Ilmu Penyakit Dalam Jilid II edisi $V$. Jakarta: Interna Publishing.

Sustrani, Lanny, (2008) .Hipertensi. Jakarta : PT Garmedia Pustaka Utama. 